\title{
Historical Aspects of Fires, after Impact, in Vehicles of War
}

\author{
W. JOHNSON \\ School of Industrial Engineering \\ Purdue University \\ West Lafayette, Indiana 47907, USA
}

Key words: Fire Vehicles Historlcal

War Impact Damage

\begin{abstract}
Bellcose, destructive engagements between land, sea and alr vehicles throughout history are revlewed, where fire has been the primary destructive agent or has been a powerful secondary consequence of the mechanlcal impact of projectlles.
\end{abstract}

\section{INTRODUCTION}

The subject of fire in vehlcles of war was strlkingly brought to the attention of the people of the U.K., (and Indeed elsewhere), by the Falklands War of 1982. News-reel coverage of incidents in whlch shlps were hit and set on flre by Exocet missiles was extensive and the publlc in Britlan engaged in much discussion about the reasons for the vulnerabllity of thelr present day naval craft to flre, especlally after misslle attack.

Studying the effects of flre in, or caused by, vehlcles of war, brings about a reallsation that flre has long been a dellberately offenstve weapon and sometimes an unforeseen horrendous secondary consequence of the use of misslles.

This short paper endeavours to draw together some of the more general but conspicuous features of fire as encountered historically in vehicles of war. There are, necessarlly, lacunae in this treatment of the subject because of want of information about weapons' effects and because the toplc has not, apparently, been greatly researched in extenso.

The revlew begins with brlef hlstorical facts and references to pre-Christian and Roman naval operations in whlch flre was employed and these are followed by notes, mostly about Greek fire and its use predominantly by the Byzantines, wlth some interspersed remarks drawn from Needham's writings on flrearms and gunpowder in anclent China. Little has been found about fire in vehicles of war at the time of the Middle Ages and indeed up to the relatively modern post-1600 A.D. era. From simple reflection it is easily concluded that untll the 20 th. century, it is naval vehicles that must be considered the princlpal toplc of interest, since the two large categorles, automotive vehicles and alrcraft, previously had no exlstence, whilst railways or locomotlves have been operating for but a century and a half. For a survey of the subjects of fires after 1 mpact in non-warlike vehlcles, see ref. (1).

\section{FIRE IN WAR VEHICLES}

\section{Pre-Christian Naval Engagements Using Fire}

The maximum speed of pre-Christlan warships has been estimated at between 6 and 13 knots, ${ }^{2}$ it tending to increase in proportion to the number of super-imposed banks of oars. Phoenlclan biremes, and Greek trlremes and penteconters are known of from several centurles B.C. ${ }^{3}$, and many lllustrations of them appear on anclent vases. 
For penetrating the hulls of the ships of thelr adversarles beneath the water, solldly pointed underwater rams ${ }^{3}$ were employed. Besides these it was common to throw fire and shoot flammable arrows and the like from towers speclally bullt on warships.

Chapter 2 in refs. (4), notes several consplcuous pre-Christlan warllke encounters in whlch the dellberate promotion of on-board fire was attempted, thus,

1. In the battle of Samalls, 480 B.C., the Greeks placed red-hot coals in kettles on the end of long spars and tlpped them into enemy (Persian) ships.

2. In the battle of Actlum in 31 B.C., heavy welghts and balls of fire were thrown on. to Roman shlps from wooden towers bullt on to the vessels in Mark Anthony's fleet.

3. It is recorded that Archelaus in a war (of 87 B.C.) agalnst the Romans, washed a wooden tower with a solution of 'alum' (sic) to render it fle resistant. Apparently however, this alum seems not to have been used to protect shlps' tlmbers against fire and in any case was not present-day alum (see the discussion in ref. (5)). However, Partington ${ }^{9}$ does attribute the use of real alum to Greeks for flre-proofing timber and to Romans for flre-proofing selge englnes in 296 A.D.

4. Recall that Archimedes was supposed to have set fire to Roman shlps using metal mirrors.

\section{Principally on Greek Fire}

To convey a sense of proportion about the true importance of fre in the whole of early warfare, it is well to recall an excerpt from Oman's "The Art of War In the Middle Ages, A.D. 378-1515,

“... Greek fire .... though its Importance in pollorcetles (slege warfare) and naval flghting was considerable .... was a 'minor englne of war' and not comparable as a cause of Byzantine success to thelr excellent strateglcal and tactlcal system ...."

However, the Impresslon which Greek Fire could have on troops is well instanced by the following extract from a Russian chronlele, ${ }^{7}$

"The Greeks have something whlch is like lightning from heaven, and, discharging 1t, they set us on flre; that is why we did not defeat them."

The above quotation refers to a naval attack on the Russians by the Byzantine navy in $\mathbf{9 4 1}$, when a Russlan armada was virtually annlhllated by the use of Greek flre. Of the year 871 A.D., there is a report of Byzantine flre-shooting ships "capable of turning the very stones to clnders". Greek fire was a notorlous 'secret weapon' for which natlons from Eastern Europe sought 'samples' of this 'priceless commodity' from the Byzantine Emplre. One early 13th. century manuscrlpt ${ }^{7}$ shows an artist's Idea of such an encounter. Early occasions as in the 7 th. century when "flre shlps" were fitted with slphons are noted in ref. (8).

Scoffern In 1858, gave an early and relatlvely lengthy discussion of the origlns of Greek fire, whilst a shorter different survey on Inflammables and Explosives, is to be found in the book published in 1906 by Cowper. ${ }^{8}$ The most slgniflcant work of scholarship on this subject is undoubtedly that from Partington" in 1960, entitled "A History of Greek Fire and Gunpowder,"

The ingredlents of Greek fire, varlously stated to be mixtures of any or all of sulphur, resin, quick-lime, pitch and turpentine, or naptha, ${ }^{\dagger}$ Needham categorlcally states to have been used from the classlcal perlod of Greece up to the 14th. century A.D., by whlch time gun-powder had been developed or invented. Thls flre was projected by bellows or pumps (from shlps or even land vehlcles) on to enemy vessels which took flre and caused black smoke which could seldom be suppressed. The projected incendlary materlal, say the naptha, was llkely to have been thlckened by resinous materlals and sulphur since the jet would otherwise have been dissipated too quickly by the alr.

\footnotetext{
$\dagger$ From tiquid petroleum from oil wells in Iraq" ${ }^{n}$ p. 28, ref. (9).
} 
The common ldea that the Chinese used gun-powder only for flreworks, Needham holds, is quite false. ${ }^{11}$ That it was developed solely by artisans he maintains is also untenable; he claims it was the outcome of 'systematic' explorations by Taoist alchemists.

The name 'wet fire' or 'wlld flre' has been used to describe the 'flre' ejected from slphons; and yet another varlant seems to have been 'sea fire' whlch probably included salt-petre; ${ }^{10}$ the latter went out of use in 1200 A.D.

Needham," has descrlbed a "flre lance' of the 10th. century which was used to destroy rigging and woodwork; when flrst used it was held manually by flre-weapon soldlers. Later it was made of bamboo, (he clalms it to be the archetypal gun barrel) and was called an eruptor; it is indicated to have been long and nearly one foot in diameter, belng mounted on a framework of legs and even wheels for mobllity. Thls device is supposed to have shot flaming projectlles. Edward Gibbon's Chap. LII of his

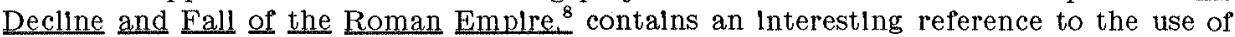
copper tubes in the bows of shlps, for projecting Greek flre in assaults on Constantinople in the late 8 th. century.

Table 1 from ref. (1) seems to show that knowledge of gun-powders, allegedly flrst used as a 'match' for flame-throwers In 919 A.D., was brought to Europe from Chinese lands in the second half of the 13th. century by Moslem and Christlan merchants and adventurers and by proselytlzing Nestorlan prlests. The later forms of gun-powder were brlsant with the nitrate proportion in compositions increased to give destructive explosions.

Greek fire was employed in Western Europe in the Middle Ages for burning towns, the very common roofs of straw or shingle belng highly vulnerable to flre. In 1379 at Oudenarde, Inhabltants covered thelr houses with earth to resist flre hurled Into the basse-cour.

Generally, anclent flre extinguishers were water, sand, dry or molst earth and manure or urlne (whlch contaln phosphates) and probably salty vlnegar.

The same applled in respect of bridges and shlpping. A Brabanter wooden bridge over the Meuse was attacked by the Guerlols wlth 'engins feu' in 1388 and caused to collapse into the rlver. At Breteull in 1358, those beselged were provlded with "canons jetant feu...' to deter attackers on advanclng towers. ${ }^{12}$

If we Include Mlddle Ages selge engines as early vehlcles In our review then notice may be taken of a full description of the use of the Sow or Cat (the anclent VInea) in the seige of Jerusalem in 1099 which was given by Wlllam of Malmesbury. The Sow is essentlally a low, moblle covered timber construction protecting advancing engineers engaged in minlng the foundations of walls. Mines prepared in about 1200 A.D., were caverns in whlch plllars of wood, supporting lncumbent walls, were smeared with pitch, surrounded with combustlbles, and then fired to allow collapse. Also, Berefrelds or moderate-sized towers were employed as a stage for attacking soldlers contesting defenders on ramparts. The defenders it is reported, 'trusted their whole securlty by pouring down bolling grease and oll upon the Tower'. This was replled to by the Franks by throwing 'faggots flaming with oll on to an adjolning wall tower". Wet animal hides were frequently drapped over wooden walls to protect structures.

Cowper $^{8}$ notes the wide and early use of inflammable propellants for projecting rockets and fire pots from tubes In 'early Indla' by the Slamese, at Delhl by Mahoud V agalnst Timur Beg and their throwing by catapult in 1290 by Ala-ed-din. He quotes too, examples of prolected lgnited moss on to burning villages by South American Indlans. Cowper's summary that "Inflammables for war derive from Assyrla which bequeathed it as Median flre to Byzantlum - the Arabs stole (sic!) it from the Greeks and the Europeans learned (slc!) it In the Crusades", may well be as true as Needham's line of suggestion in imputing to it a unlque orlgin in Chlna. Partington, ${ }^{\theta}$ again, devotes whole Chapters to this subject. It is not all Improbable that many pyrometting practices were developed in several societles independently of one another, much as is sometimes the case with sclentlflc discoveries. 
Partington devotes a chapter to Incendlarles of war and especlally mentlons several Muslim flre books which show among other thlngs reclpe proportlons for gunpowder and the use of naptha.

\section{Fire Ships and Hot Shot}

Wooden naval shlps have always feared Incendlary attack - an Increasing threat onward from the time of the Introduction of Greek flre. Cowper says that Procoplus in his history of the wars of the Goths of Africa describes the use of Median fire and Genserlc is sald to have used fire shlps against the Greeks in the 5th. century A.D.

Fireshlps were used, successfully, agalnst Drake at Cadlz in 1490 by the Spaniards, and the Dutch flled shlps with explostves to cause exploslons in the Duke of Parma's fleet which was beselging Antwerp In 1585. In battles agalnst the British in the latter half of the 17th. century, the Dutch always had on hand a number of specially combustible craft. Fire was used to great advantage in a Dutch rald (on Engllsh ships) up the river Medway in $1867 .^{*}$

Fire shlps consisting of flshing smacks of faggots and pitch were apparently to be used by the English to attack the Spanish armada in 1482 in the Calais Roads but as they could not be assembled rapldly enough, elght small shlps of the fleet, probably victualers, were prepared. A Spanlsh screen of protectlve patrol boats mostly fled as tide and wind bore the flred ships into the assembled armada. These flre shlps had 'shotted' guns and thelr explosions added to the panic Induced. The starting of ship fires In the armada apparently falled completely but they were successful in as far as they Induced the 120 Spanish ships to sllp or cut thelr cables to escape in terror.

It has often been observed that, certalnly in the late 18th. century, it was rare for ships-of-the-line to be sunk by gun flre: burning or capture ${ }^{\dagger}$ was the rule. In a DutchEnglish naval battle of 1784 , the Dutch had at least seven and the Britlsh two ships burnt or blown-up. In the battle of Trafalgar no shlp was sunk on elther slde as a direct consequence of enemy action. ${ }^{14}$ Though fire shlps were included in most large fleets there is little evldence that they directly caused flre disasters. But fires in wooden shlps were a terrible threat and thelr menace generally led to the Britlsh Navy taking thorough precautions against them.

Flre shlps were used as recently as the flrst quarter of the 19th. century, for example In 1809 by an Engllsh fleet under Lord Cochrane agalnst French ships at anchor In the Basque Roads, and in the War of Greek Independence the Greek fireships used successfully against the Ottoman navy led to their command of the sea.

Notwithstanding the panle whlch tended to be Induced by flre ships hampering the movements and dispersal of a fleet, they could be easlly sunk by enemy fire or towed away by enemy boats. Also, experlence showed that premature exploslon by those putting fire shlps Into position could often be fatal. Typlcally, fire shlps of later times conslsted of bullding 'a fire chamber' between decks from the Porecastle to a bulkhead constructed abaft of the malnmast. Thls was fulflled with resin, pltch, tallow and tar and with gunpowder in Iron vessels. The gunpowder and the combustlbles were connected by powder tralns and by bundles of brushwood ('bavins'). Servlce with these fle ships was so dangerous that the reward of $£ 100$, or In lleu of it a gold chaln, was given by the British Navy!

It was long the practice when wooden naval shlps were in vogue to exchange hot shot or cannon balls in the hope that flres would be started or ammunition caused to explode on the enemy's ships. It was infrequent for shot to penetrate the sides of ships

\footnotetext{
* Interestingly, it is recorded that Newton heard the noise of this raid from as far away as Cambridge and was able to pinpoint the time of day and deduce that serious losses had been incurred.

$\dagger$ Firing à ricochet to demast ships and thus leave them to be boarded later or at the mercy of the weather was a serious 18th./19th. century tactic, of the British Navy. See W. Johnson and S.R. Reid, 'Ricochet of Spheres Off Water', J. Mech. Eng. Sci., 17, 71-81, 1975.
} 
of a fleet which were often three feet thlck in hard woods such as oak, teak and mahogany. In ref. (13) it is implled that it took a close range $32 \mathrm{lb}$. shot from a $10 \mathrm{ft}$. long cannon to do so. In a long selge of Glbraltar by wooden French shlps in the 1780 's, red hot shot was apparently flred from the land fortress. ${ }^{14}$ Many reports exlst of shlps exploding after gunpowder carrled in magazlnes had been heated by unintentional ship flres or penetration by misslle fragments.

The invention of red hot shot, in 1579, is attrlbuted by Brigadier O.F.G. Hogg in his foreward (page v) to the book, Great Art of Artillery (Artis Magnoe Artillerloe) by Polish General C. Simlenowicz, to the KIng of Poland. The book Itself is a fasclnating text book for would-be pyrobolists rather than artllerists; it was originally published in Latin in 1850, then translated into French and from French into English in 1729. The varlety of fire projectlles treated by hIm exceeds at least twenty. Simlenowlcz says in his Chap. XVII that red hot shot was "far from belng modern" and refers to Dlodorus Siculus testifying that the Tyrlans projected it into the "works of Alexander the Great". Also an occasion is mentloned when in a war of 1598 a red hot ball penetrated a tower, fell Into a barrel of gun powder and destroyed the entlre structure. Gibbon (see above) in his Chap. LII refers to the launching of red hot balls of stone and Iron in the 8th. century as well as to inflammable oll deposited in flre shlps.

Under this heading brlef mention needs to be made of incendlary shells flrst introduced in 1480 and varlously developed since. In the main these were spherlcal carcasses or shells contalning Ignitable compositions which were vented radially to allow the egress of flame. Martin's shell (c. 1860) was fllled with molten Iron and used agalnst shlpping by the Brltish whllst another deslgn due to Hodgkinson (c. 1914) was used against Zeppellns (See O.F.G. Hogg, Artllerv. Archon Books, 1970, p. 171).

Flring fleets at anchor as described above merely underlines the perennial risk from flre in any gathering together of vehicles, e.g. of buses and coaches, see ref. (23). We may mention that the blggest naval holocaust of the 19th. century occurred in the U.S.A. at the Norfolk Naval Base when Southern sympathlzers torched warships on the occasion of Virglnla's secession from the Union In 1861 .

The effects on wooden shlps of a lightning strlke, namely 'rlgging set on flre, masts spllt and severed to pleces...' was reported in writing in 1775 by Bathae. ${ }^{3}$ The reason for the latter was probably due in part to the anlsotroplc character or the graln of the wood; Its molsture when Instantaneously vapourlsed 'explodes' the wood whllst axlallty in the flow of electrlclty leads to severing or 'chlvering'. Early references to this (end of the $17 \mathrm{th}$. century), and closely related work on fulgerlte formation is given in ref. (24).

Lightning conductors had been introduced and were nearly universal in British naval vessels by the beginning of the $19 \mathrm{th}$. century.

\section{Armoured Fighting Vehicles and Fire in the 20th. Century}

In all milltary flghting vehlcles fire poses a huge and constant threat. Not only does it destroy expenslve structures and equipment but the personnel, aside from purely humane considerations, are frequently expenslvely equlpped and costly to traln. The flame-thrower has already been mentioned in an historlcal context $t^{\dagger}$ as an anclent

\footnotetext{
$\dagger$ Republished by S.R. Publishers Ltd, 1971, Wakefleld, England and Scholar Press Lid., Menston
Yorkshire, U.K.

* Fulgerites: tubes or vitrifled sand found in the earth after a lightning strike, so-called after the Roman god of lightning, Fulger.

$\ddagger$ Compare Gibbon (Chap. LIII) who refers to the use in (probably) the 8th. century of a "mischievous engine that discharged a torrent of the Greek fire, the feu Gregois ..." In a footnote he says that Joinville described something as "like a winged long-tailed dragon...with the report of thunder and the velocity of lightning..." "It was shot with a javelin from an engine that acted like a sling", seemingly a mangonel, but more likely a balista.
} 
naptha projector whlch was certalnly in use according to Needham ${ }^{\dagger}$ in 919 A.D., when gun-powder of a kind was flrst Identlfled as belng a 'match' for naptha. A British orlgin and development for napalm has been clalmed in ref. (15). Flame Fougasse as a one-shot weapon was apparently developed In about 1840 to project onto advancing tanks about one ton of burning petroleum. ${ }^{\dagger}$ The moblle Churchill flame-throwing tank was later developed to assist in clearing operations and a slightly fictionallsed account of this Crocodlle as used operationally in World War II is glven in 'Flame Thrower' by A. Wilson. ${ }^{18}$ Some detalls as outlined by hlm follow.

The flame-projector was mounted in the front of a Churchlll Mark VII tank with the flame-gunner alongside the drlver. Four hundred gallons of heavy vlscous flame fuel, (of petrol, naptha and rubber - a crude form of napalm) was carrled in a seven-ton traller connected to the tank by an armoured link contalning the fuel plpe. The fuel was projected from the nozzle gun by means of 350 p.s.l. of nitrogen, - actually reduced from 5000 p.s.l., as stored in five steel 'bottles' carrled in the traller. The 'rod' of fuel was Ignited by a Jet of burning petrol that passed between two electrodes. The gun had a range of 90 yards and could flame continuously for two minutes.

In 'The Secret War' by Gerald Pawle, ${ }^{17}$ a 'Cockatrice' is described in chapter 4 as designed malnly by the Lagonda Car Company. It fled diesel oll and used 8 gallons of fuel per second. Later models fired 200 yards; these were developed by the Army and the Anglo-Irantan Oll Company. The Cockatrlce consisted of a $2^{1 / 2}$ ton lorry, "Invulnerable" to fire, possessing a tank holding 2 tons of fuel with the flame thrower Itself mounted in a turret behind the cab and operated by a gunner in the turret. The all-up welght was 12 tons.

It was trled at sea after installing it on a trawler, by flring it vertically against low-flying alrcraft: the plllar of flame was over $400 \mathrm{ft}$. hlgh, its helght being enhanced by the heat of the fuel. However, in tests with even up to one half an alreraft wing belng driven through the flame, no serlous damage to the plane ensued. A few naval flame-throwers were produced and Installed on sea-coasters but thelr maintenance was difficult; very high pressures had to be malntalned and unless well handled, shlps and thelr crews were llable to be smothered in tar and oll.

It seems that German experience after testing a somewhat simllar devlce whlch projected llghted fuel from a pipe and nozzle which ran up a ship's mast, showed it to be a fallure.

Tests of the abllity of assault landing-crapt to enter a harbour with the infantry passing through the fire of any flame-thrower mounted on a breakwater, showed they needed no canopy. To flre a flame along a stralght trajectory when slightly depressed was sald to be very difflcult. Tests showed that dummles, paper and mice in the bottom of craft, emerged without scorching or polsoning.

Impact leading to fire and/or explosion is promoted when some modern tank armours are penetrated by copper-11ned shaped-charges; the temperature of local target material is raised but particularly it has been noted that hot spall particles are efected through tank compartments. If they are small (malnly aluminlum), they may burn so rapldly that effectively an explosion occurs and they may have a lethal effect on a tank crew. Suppresston is provlded by plastic liners.

A shaped-charge passing through a partially fllled container of gasollne, or volatlle hydraulic fluld, renders it rapldly combustlble when heated and atomlsed. Dlesel fuel thus tends to be used and its tank contalner located outside the crew compartment armour. Shaped-charge Jets may also penetrate ammunition, but steps are now taken to quench exploston propagated through propellant charges by surrounding them with an extingulshing agent.

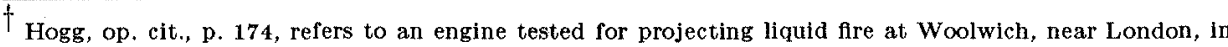
1709.
} 


\section{Airships}

Flre sources in alrshlps and catastrophlc experlences with them are outlined in refs. 18 and 19; also many references are quoted thereln which detall well known disasters, for example Delghton and Schwartzmans' Alrshlpwreck", ${ }^{20}$ Because the risk of flre aboard alrshlps has been so heavlly reduced, malnly due to ceasing to use hydrogen as the llfting gas - and for several other reasons ${ }^{21}$ - many governments have become interested in developing them for off-shore patrolling work such as protecting oll Installations and flsherles, etc., and as having antl-submarine capabllty. They have been thought of as capable of carrylng alr-to-alr and other missiles and torpedoes, all both cheaper and faster (at up to about $100 \mathrm{knots}$ ) than conventional surface ships, able to have light armour and belng easlly maintalned wlth a small crew. It has been stated that such airships have a lower radar proflle and llttle infra red and noise emission, which makes them less attractive targets for homing misslles.

Stepping back Into history, the Britannlca Encyclopaedia (1947) gives a detalled historlcal account of air balloon development in which instances of disastrous flres occur, many simllar in result to contemporary disasters typifled by a 1983 report in the Sunday Times of a $140,000 \mathrm{ft}^{3}$ hot air balloon belng projected $200 \mathrm{ft}$ in the alr after a propane cylinder had exploded.

By contrast, 'My Alrships' is an interesting but little known book, ${ }^{24}$ by A. SantosDumont (1873-1937) about hls alrship development and flying activlties between 1900 and 1905. Among many of his observations, this pioneer thought that the flrst practlcal use of alrships would be found in war, (p. 80). He recorded that he had no fear of flre (p. 45), and that he could see but one dangerous posslbillty of it (p. 48), namely, "that of the petroleum reservolr taking flre by a retour de flamme from the motor" - (a sucking back of flame). Thls Innovator, contrary to the subsequent experlence of others, appears to have suffered no fire disasters desplte his large number of journeys.

\section{20th. Century Naval Ship Fire Safety ${ }^{25}$}

"Naval ships are often floating ammunition farms and fuel dumps housing multi-millon dollar (equipments)... and densely packed with personnel..."

"The most common feature of modern naval warfare is internal flre caused by shells bursting among combustlbles and explosives."

This topic is reputed to have recelved much attention from about the time of the Russo-Japanese war (1904-1805) when flre, smoke and burning paint on the Russian shlps, together with acrid gas from Japanese gun powder ('shimosa'), had devastating effects.

In about 1880 the coal bunkers of battleshlps were dellberately placed between the outer skin of a vessel and its vital organs. It was noted from tests in 1878 that $2 \mathrm{ft}$ of coal had the reslsting power of 1 inch of Iron (ref. 28, p. 412) and was not set on fire by shell (l.e. gun flre) explosion. However, tests in 1904 using torpedoes showed that simllar protection was not avallable agalnst them.

From World War II to the mid-1870's, major flre disasters aboard naval ships and aircraft carrlers especlally, hardly diminished.

H.M.S. Hood, a 41,000 ton British capltal ship, (having a deck only 3 inches thick and turret roofs only 5 inches), apparently never modlfied for the containment of powder flash from burning powder magazines after experlence in World War 1 , suffered a direct hit from The Blsmark which caused a great fire that quickly led to the explosion of the magazines. The German shlp suffered nearly 400 direct shell hits and $\theta$ torpedoes and only sank after belng scuttled. Oscar Parkes ${ }^{26}$ in his huge and authoritative volume on Brltish Battleshlps, 1880-1950, notes that propellant cordite whlch exploded when exposed to flash in the magazines, explains the loss of battle crulsers at The Battle of Jutland. A different treatment of cordite (separation into two sectlons) by the Germans did not glve rlse to explosion desplte being flred. Parker notes that among the German battle crulsers assoclated with nine penetrations there were elght flres but no explosions (p.641 and p. 679). 
World War II made clear the vulnerabllity to conflagration from oll, avlation gasollne and explosives of many Japanese and Amerlcan alrcraft carrlers which had only lightly armoured decks; many shlps were lost due to these, and after attack by bomb and Kamikaze attacks. This reflects the fact that a new, essentlal and far reaching lesson for sea power (after the battle for Mldway) was that centurles of dependance on blg shlps carrying blg guns was ended and their place was to be taken by aircraft carrlers. Many battery explosions and electrlcal fires in U.S. submarlnes occurred between 1949-1955, whllst In the late 1960's, three carrlers were the subjects of conflagrations due to 'burning pyrotechnics' and deck fires fed by alrcraft ordnance and fuel ignitions.

The 1970's saw In fires on the U.S.S. Forrestal and U.S.S. Saratoga, Impassable passage-ways affording flre spread and fire propagatlon along wire and cable-ways. Most traumatic was the flre resulting from the collision of crulser U.S.S. Belknap and carrler U.S.S. J.F. Kennedy in 1975. The mast and aluminlum superstructure of the former were sheared off by the overhang of the Kennedy's angle deck sponson; most damage resulted from the melting of aluminlum structure due to fire, ${ }^{\dagger}$ fed early on by

JP-5 fuel pouring from the sheared flight-deck fuel risers on the U.S.S. Kennedy.

Hydro-carbon fles are combated best by excluding alr and reducing the vapourisation rate of applied llquid Aqueous Fllm-Forming Foam (AFFF) concentrate (mixed with sea water to glve $6 \%$ solution). Halon gases in machinery spaces extinguish fires by interfering with the combustion chain reaction.

Fire protection design against present-day flre threats to ships are outlined in ref. 4.

OIl flre extingulshment it is held, may be posslble by using pressurised contalners of water and very flne mist nozzles; the water spray droplets become steam which absorbs thermal energy and cools the flre.

A Fllght-Deck Washdown System was introduced after the unfortunate experlences with the U.S.S. Forrestal (1967) and U.S.S. Enterprise (1989). The system can deluge all or part of a flight deck with AFFF through spray nozzles on a flight deck or along a deck edge.

Items for upgraded flre protection on naval shlps include, among other things, lumlnescent markers to make clear escape routes to weather decks, refractory felt for the protection of aluminlum superstructure, Improved magazine sprinkler systems and flre spots for cable ways.

For detalled papers about missile magazine protectlon, see refs. (29) and (30); Halon Expansion foam fire protection systems for shlps, are discussed in the Naval Englneers Journal of recent years.

\section{Mainly About the Use of Aluminium in Naval Vessels ${ }^{31,32}$}

Aluminium has wide use in modern naval craft, especlally in the hull and superstructure in order to reduce welght, Improve stabllity and to help conserve fuel. Unfortunately, the relatively low temperatures vis-a-vis steel at whlch aluminium loses its strength, renders flre threat of enhanced importance. Thus, alongside the use of aluminlum it has become necessary to develop light welght thermal mitlgation systems. This leads to trade-offs as between flre resistance (or time to structural fallure under flre conditions) and weight, in the deslgn of hlgh performance craft.

\footnotetext{
The ability of metals when sliding, cutting or dragged under pressure against another surface to reach a high flash temperature and thus to be an energy source sufficiently high to ignite avalable vapourised fuel is empirically addressed in ref. (27). Ref. (28) seems to be the most recent scientiffc paper in which junction growth and heat due to the work of plastic deformation, are incorporated into the heat-transfer equations of the Jaegar-Archard theory and provide results which compare well with those of experiment for estimating flash temperatures.
} 
Aluminlum is about one third the density of steel but has about the same ultimate strength, whlch Impresslvely contrasts the strength of these two materials over a large range of temperatures. Whilst the varlous aluminlum alloys do perform differently, they do not do so signlficantly over the temperature range of interest; certalnly at $700^{\circ} \mathrm{F}$ all aluminium strength has effectlvely disappeared. When actlve systems are inadequate, malfunction or by human error are not released, then passlve systems are relled on. Particularly this means minimising serlous flre threat where aluminlum is concerned; time is purchased prlor to active fire protection systems belng operated, by adding thermal insulation. Fire prevention, early fire detection and rapld flre extingulshment are essentlal active Peatures, especlally on aluminium craft. Examples exist of aluminlum bulk heads, aluminlum hulls and indeed whole ships being melted down; in contrast these items in steel do not.

Fire Insulation materlals currently used are mineral wood, refractory felt or blanket polyisocynurate foams, polyimide foam and flbre glass, all with densities in the range 2.5 to $7 \mathrm{lb} / \mathrm{ft}^{3}$. With a temperature of $450^{\circ} \mathrm{F}$ as a fallure level, one hour of protection is given by about $1^{3} / 4$ inches of $4 \mathrm{lb} / \mathrm{ft}^{3}$ refractory felt. Note however that heated and $\operatorname{lgnlted}$ isocyanurate foams glve off large amounts of HCN gas.

\section{Naval Vessels in the Falklands' War" of $1982^{21,10}$}

Fire and its consequences in flghting shlps in the Falklands' War highlighted the subject's enormous Importance and underlined the cost of taking, or neglecting to take, Its $11 \mathrm{kellhood}$ serlously enough. Especlally, a lesson of the Falklands' War of 1982 was the need to reduce smoke in battle damaged warshlps; this was made clear when the destroyer, HMS Sheffeld was hit at 8-15 ft. above the water-line, and set on fire by a Super-Etendard $600 \mathrm{mph}$ Exocet misslle of $658 \mathrm{~kg}$ welght, which carrled a $164 \mathrm{~kg}$ warhead. It is reported that within minutes of it strlking the shlp, smoke poured from deck openings at $100 \mathrm{ft}$ and more from the point of $1 \mathrm{mpact}$. The shlp was set on flre and burning solld propellant was scattered, as well as the misslle's own fuel; these in part created the massive smoke pall. Doubtlessly the shlp's ventllating systems contrlbuted to the rapld spread of flre as well as the shlp's own materlals and the avallabllity of cable ways. \# Palnt on the shlp's slde came off around the zone near to the missile and close to the reglon of penetration the hull glowed red. Though fought for several hours it was eventually abandoned out of fear that the magazine mlght explode.

H.M.S. Coventry was hit by several bombs whlch caused flooding beyond the design $11 \mathrm{mits}$ of the ship. Smoke rendered the operations room unusable, as much as anything because of disorlentation effects.

Of torpedoes which helped sink the Argentine troop carrler Belgrano, one was reported by the Captain to have created 'a fireball', (compare and see the references in (34)), and another 'a cloud of dirty smoke'. A huge hole was created in her bottom, amidships, and her bow broke off.

H.M.S. Antelope suffered from an unexploded bomb that detonated when defusing was in progress. The shlp burned for many hours apparently with the aluminlum superstructure remalning intact and not belng responsible for her loss.

The Altantic Conveyor recelved one or two Exocet misslles and burned for two to three days, but the superstructure on this occasion distorted without collapsing.

\footnotetext{
* Evidence and sources for many remarks in this section will be found intersperced among two references stated.

\# Remarks concerning pre-routing ventilation systems to permit smoke removal and for improving ventilation fans for de-smoking have been made. Existing fans apparently cannot remove hot gases since the fan motors cannot withstand the temperatures. Eductors from exhaust systems have been recommended for investigation.
} 
The New Scientist catalogued the following explosion-flre 'errors' as contributing to the H.M.S. Sheffield 'flre trap', though the 85 million shlp (commissioned in 1880) had the usual sprinkler systems, fireproof doors and hatches, etc.

1. Generators provlding power to fire-fighting pumps were out of action: the missile knocked-out the aft maln generator and the forward one falled minutes later.

2. Flre-flghting pumps did not work because vital parts were missing: the shlp was deficlent in small fire extinguishers since only a small number was avallable and not rechargeable.

3. In some cases, breathing equlpment contalning compressed alr was almost empty.

4. Foam mattresses burnt easlly, glving off clouds of toxlc smoke. It is reported that in the latest U.K. battleshlps, these have been dispensed with in favour of horse hair, which only smoulders and glves off smoke less rapldly than synthetlc materlals.*

5. Hydraullc fluld sprayed uncontrollably from burst plpes feeding the flres.

6. Sallors were wearing polyester ${ }^{+}$unlforms that melted on to thelr skins. Antl-flash personnel protective equlpment, e.g. hoods and gloves, was a major factor in preventing and limiting injurles from flash and blast." Multiple layers of any clothing served better than one layer; polyester or other synthetic fabrles were counter-productive.

Reports descrlbed missile blasts as going "upwards and outwards" - upwards as frequently happens In bulldings where cellings are usually the weakest of a room's containing surfaces - rupturing H.M.S. Sheffeld's deck and almost one third of the ship from galley to damage control headquarters, causing it to burst into flames with thlck toxlc smoke; "...the gaplng hole in the shlp's slde and engines fed the flames, whlch rapldly turned into an inferno".

Early allegations that in the damaged H.M.Ss Invincible. Sheffleld and Ardent. 'alumlnlum burnt' and contributed to loss have been refuted." In a recent leaflet, the (Britlsh) Aluminlum Federation felt It necessary to state that aluminlum does not burn under natural conditions, but that It does melt and vent a flre. However, that there was much flammable materlal aboard shlps at the Falklands (and as unnecessary furnishings) was conceded and that it would burn when some critical temperature was reached was unavoldable; but most of it was "fuel and ammunition followed by electrical cabling, deck and bulkhead linings and furnishlngs". Apparently, 175 mlles of cable were then to be found in a Britlsh destroyer. With H.M.S. Sheffleld it is acknowledged that the smoke and fire were chlefly the products of unspent rocket fuel from the attacking missile motor, and oll Prom the shlp's fuel tanks. Noteworthy, is the little known fact that H.M.S. Glamorgan suffered a hit from a land-based Exocet but that the major fle was extingulshed by a large hole in the deck being plated-over and other major equlpment repalrs belng performed.

A possible useful conclusion, valuable for future shlp design that has been noted is that control functions (whlch includes damage control) might be prudently separated from those of Internal command. Also that the location of generators and simllarly

\footnotetext{
* Plans to do away with oil for potato chip making are afoot too!

+ suits now provided are flame resistant. Partington ${ }^{9}$ (p. 207) mentions fire-suits for men and horses, of felt and compositions of talc and brick dust etc., being used in about the 14th. century by the Arabs!

\# Interestingly, many World War II bombers had extensive interior hydraulic lines which blew up or burned rapidly when damanged. In prisoner-of-war camps it was observed that the type of aircraft that had been flown by certain in-coming prisoners, (B-24 crews), was known by the kind of bandages for burns which they wore.

* An instance in which metal probably did burn occurred in the Le Mans (French) Grand Prix of 1955, when a Mercedes car containing an engine with a high fraction of magnesium, swerved at $180 \mathrm{mph}$ during the race and ran up an earth safety bank, somersaulted, bounced and "exploded into white-hot component parts", amid spectators, killing 82. ['Great Disasters', Treasure Press, (1976), p. 61.]
} 
'soft' vital auxllaries might be more thoughtfully distributed around ships in vlew of llkely hits from smart munitlons: and that loss of alr conditlonlng, low pressure alr and centrally-supplied services can disable weapons and command positions.

In one discussion on the latter toplc, it was polnted out that modern engine rooms are In a kind of deep plt with very hot machinery at the bottom and with volatlle and combustlble fuel oll about. Steam drench was thought preferable for putting out machlnery space flres but as noted above, "the ultimate is large quantltles of salt water with AFFF foam or some equivalent". Inert gases are generally used in weapon electronles compartments in gas turbine modules and in the engine rooms of gas turbine ships. Nitrogen is used in submarines though halogens are favoured; lower overpressure is required for flre extinguishers and personnel survive it better. Fire has to be contained for inert gases to be effectlve and large misslle holes in ships preclude this.

The U.S. Navy alrcraft carrler U.S.S. Forrestal (1966), already referred to above, was almost totally destroyed by fire after a misslle on a plane exploded on the flight deck and many died of carbon monoxide polsoning. A consequence was that a Survival Support Devlce (S.S.D.) was developed, but regretably too féw of these were avallable to British Naval personnel in the Falklands' war. (Apparently, emergency life-support apparatus holding air for 8 minutes has since been ordered). About 120,000 such units were with the U.S. fleet in 1978 and now an Emergency Escape Breathing Devlce (E.E.B.D.), has been developed to provide a 15 minute alr supply for the U.S. fleet.

\section{CONCLUSION}

It is hoped that some general appreclation of the significance of fire assoclated with fighting vehicles in a primary or secondary role over the centurles has been conveyed and that in particular some of thelr vulnerable features have been usefully noted. Thls signiflcance wlll be seen to have grown wlth time and vessel system sophistication.

\section{ACKNOWLEDGMENTS}

The author would like to thank the Leverhulme Trust which supported his diverslons into this fleld.

He also wishes to thank his wife, Mrs. S. Purlan, and Ms. Denise Evans for typlng the original script and subsequent drafts of this paper.

\section{REFERENCES}

1. Johnson, W.: Vehlcle Impact and Flre Hazards, Structural Impact and Crashworthiness Conf., Vol. I Keynote Lectures, Elsevier Appl. Scl. Pubs., 75-113, London, 1984.

2. Landels, J.G.: Englneering in the Anclent World. University of Callfornla Press, 1978.

3. a) Morrison, J.S. and Willams, R.T.: Greek Oared Battleshlps. Cambridge Unlverslty Press, 1968.

b) Torr, C.: Anclent Shlps, Argonaut Inc. Pubs., Chlcago, MCMLXIV (1984).

4. Rushton, F.: Fire Aboard, 2nd Editlon, Brown, Sons and Ferguson, Ltd., pp. 638, Glasgow, 1973 .

5. Beckmann, J.: A History of Inventions, R. and J.E. Taylor, London, pp. 184, 1846.

6. Oman, C.W.C.: The Art of War in the Middle Ages. A.D. 378-1515. Cornell Unlversity Press, 1953.

7. Obolensky, D.: The Byzantine Commonwealth, Sphere Books, pp. 246, 1974. 
8. a) Scoffern, J.: Projectlle Weapons of War, Richmond Publishing Co., 50-63, 1858.

b) Cowper, H.S.: The Art of Attack. W. Holmes Ltd., Ulverston, 1908, and reprinted by E.P. Publishing Ltd., 280-285, 1877.

c) Gibbon, E.: Decline and Fall of the Roman Empire. Vol. V, 1802.

9. Partlngton, J.R.: A Hlstory of Greek Elre and Gunpowder, W. Heffer and Sons Ltd., Cambrldge, 1860.

10. : Brlttanica Encyclopaedla: Greek FIre, 18th Edn., Vol. 10, 1946.

11. Needham, J.: Sclence In Traditional Chlna, Harvard Unlversity Press, Cambridge, Mass., Ch. 2, 1981 .

12. Hewltt, J.: Anclent Armour and Weapons In Europe. Vol. I, J.H. and J. Parker, Oxford, 1860 .

13. Harbon, J.D.: The Spanish Shlp of the Line, Sclentlfle Amerlcan, December 1984.

14. Browne, D.G.: The Floating Bulwark: The Story of the Fighting Ship: 1514-1945, St. Martin's Press, N.Y., pp. 134, 1883.

15. Lloyd, G.: Letter to The Times, 18 June, 1982.

3.6. Wilson, A.: Flame Thrower, Bantam Books, 1884.

17. Pawle, G.: The Secret War. Transworld Pubns., 1959.

18. Johnson, W. and Walton, A.C.: Airshlpwreck: Analysis of Safety in Rigld Airshlps In terms of Impact Mechanics and Fire, 5th. Sym. on Engineerlng Applications of Mechanles, Ottawa, Canada, 237-241, 1080.

19. Johnson, W.: Structural Crashworthiness, Eds. N. Jones and T. Wlerzblckl, Analysis and Structural Damage in Airshlp and Rolling Stock Collisions, Butterworths, London, 417-439, 1983.

20. Delghtor, L. and Schwartzman, A.: Airshipwreck, Jonathan Cape, London, 74, 1978.

21. Johnson, W.: Crashworthlness, Vol. L. Ed. G.A.O. Davles, (Conf. London, 1984), Chapter 3, Vehlcle Impact and fire Hazards, Elsevler, 74-114, 1984.

22. Santos-Dumont, S.: My Alrshlps, Dover Pubns., N.Y. 1873, (orlginally printed in 1904).

23. Johnson, W. and Walton, A.C.: Fires In Public Service Vehicles, (Buses and coaches), In the U.K., Int, Veh, Des. 2 (3), 322-334, 1981.

24. Williams, D.J. and Johnson, W.: A Note on the Formation of Fulgerlties, Geologlcal Magazlne, 3, 293-280, 1981.

25. a) Pohler, C.H., McVoy, J.L., Carhart, H.W.,Leonard, J.T. and Pride, J.S.: Fire Safety of Naval Ships: an Open Challenge, Naval Englneers' Jnl. 21-30, April, 1878. 
b) Gustafson, R.E. and Schab, H.W.: General Concepts for a Combined HalonHigh Expansion Foam Fire Protection System for Shlpboard Application, Ibld, 2432 , February 1973.

26. Parkes, O.: Brltish Battleshlps, 1860-1950, Archon Books, 1972, pp. 701.

27. Alrcraft Crash Survlval Design Gulde Vol. III - Alrcraft Structural Crashworthlness. D.H. Laananen, et.al., U.S. Department of Commerce, ADA 08914,1880 .

28. Lingard, S.: Estimation of Flash Temperatures in Dry Sliding, Proc. Inst. Mech. Engrs. Vol. 198c, No. 8, 91-97, 1884.

29. Seeger, B.F. and Lapp, R.H.: Water Injectlon: A New Protective System for Magazines, Naval Engineers' Jnl. 719-722, November, 1959.

30. Marcus, S.W.: Protection of Deep Stowage Misslle Magazines, Naval Engineers' Jnl.s 55-259, February, 1872.

31. Ventrlgllo, D.R.: Fire Safe Materials for Navy Ships, Naval Englneers' Jnl., 85-74, October, 1982.

32. Winter, A. and Butler, F.: Passlve Flre Protection for Aluminlum Structures, Naval Englneers' Jnl.e 59-66, December, 1975.

33. Walker, J.W., Capt.: Lessons of the Falklands, Naval Engineers' Jnl.. 129-132, July, 1983.

34. Wllliamson, B.R. and Mann, L.R.B.: Thermal Hazards from Propane (L.P.G.) Fireballs, Comb. Scl, and Tech.s 25, 141-145, 1981. 
